\title{
Prediction of Mathematical Models of the Drying Kinetics and Physicochemical Quality of the Chili Pepper
}

\author{
Semirames do N. Silva ${ }^{1}$, Joana D’arc P. de Matos $^{1}$, Polyana B. da Silva ${ }^{1}$, Zanelli R. T. Costa ${ }^{1}$, \\ Josivanda P. Gomes ${ }^{1}$, Luís Paulo F. R. Silva ${ }^{1}$, Agdylannah F. Vieira ${ }^{1}$, Bruno A. de Melo ${ }^{1}$, \\ Dalmo M. de B. Primo ${ }^{1} \&$ Hofsky V. Alexandre ${ }^{1}$ \\ ${ }^{1}$ Federal University of Campina Grande, Paraiba, Brazil \\ Correspondence: Semirames do Nascimento Silva, Federal University of Campina Grande, Paraiba, Brazil. \\ E-mail: semirames.agroecologia@gmail.com
}

Received: August 31, 2018

doi:10.5539/jas.v10n12p377

\author{
Accepted: October 5, $2018 \quad$ Online Published: November 15, 2018 \\ URL: https://doi.org/10.5539/jas.v10n12p377
}

\begin{abstract}
The present work had as objective to determine the kinetics of drying of the chili pepper, to adjust different mathematical models to the experimental values as a function of the water content and to characterize the same in it's in natura form and after the drying in the temperatures of 60,70 and $80^{\circ} \mathrm{C}$. The samples were weighted periodically until reaching the equilibrium. The mathematical models of Wang and Singh, Henderson and Pabis, Newton, Page and Thompson were adjusted to the experimental data. The best adjustment was determined in relation to the highest values of the coefficient of determination $\left(\mathrm{R}^{2}\right)$ and Mean Square Deviation (MSD). The obtained results showed that the drying of the pepper is influenced by the temperature of the drying air. It is concluded that the model of Henderson and Pabis was the one that best fit to the experimental data. The increase of the drying temperature promoted a reduction in the time required for the peppers to reach the moisture of the hygroscopic balance. The parameters of acidity, lipids and proteins remained close at the different drying temperatures used, however higher when compared to the samples in natura. It can be noticed that ashes and vitamin $\mathrm{C}$ have suffered considerable decrease as the temperature increased, as a result of the chemical transformations that occurred in the peppers due to heat exposure and loss of moisture.
\end{abstract}

Keywords: Capsicum L., dehydration, mathematical models, nutritional value

\section{Introduction}

The "aromatic" chili pepper is characterized as a vegetable, belonging to the family Solanaceae and to the genus Capsicum L., and Brazil is known as secondary center of this species, being the Amazon region the one that concentrates greater diversity (Cerqueira, 2012; Araújo et al., 2013). The chili pepper has important characteristics that give quality to food, such as the remarkable aroma, sweet taste, besides possessing medicinal properties as antioxidant and anticancer activity that bring benefits to human health, which can be processed in the form of powder, flakes, pickles, marinades, sauces, canned fruit, jellies, among others (Reis et al., 2011; Santos et al., 2012).

The production of pepper for use as table condiment and industrialized food products has been increasing and is currently a very profitable olive-growing activity, including for small canning industries (Sediyama et al., 2014). The importance of peppers is attributed to their properties improving the taste, aroma and color of food. According to Rêgo et al. (2011) total vitamin C levels vary between pepper species, from 160 to $245 \mathrm{mg} / 100 \mathrm{~g}$, comparable to guava $(200 \mathrm{mg} / 100 \mathrm{~g})$ and higher than orange $(60 \mathrm{mg} / 100 \mathrm{~g})$.

The market for peppers produced via family farming is also stimulated by the agribusiness producing sauces, whose demand is increasing. In addition to the product marketed in its natural form, there is a range of pepper-based products on the national market or that use it as a component (Oliveira et al., 2014). In Brazil, pepper cultivation is of great importance because of the characteristic of profitability, when the producer adds value to the product, as well as the social importance, because it fits well with the models of family agriculture and small farmer-industry integration (Rufino \& Penteado, 2006).

Like other vegetables, the chili pepper is a highly perishable product, because it presents very short post-harvest life, making it necessary to adopt conservation techniques. Therefore, the drying, a method that consists in 
reducing the water content of the product and thus its water activity (in order to inhibit the microbial growth responsible for deterioration, besides facilitating the transport and the storage of the dry product) is the most used process to ensure the quality and stability of some products (Resende et al., 2010).

According to Faria (2012) the study and mathematical modeling has aroused the interest of several researchers for the most diverse products. In this sense Randuz et al. (2011) describe the importance of adjusting different mathematical models to the experimental drying data for the most diverse species of plants, in order to obtain the most appropriate model for each plant species. These models are generally based on variables external to the product, such as temperature and relative moisture of the drying air (Resende et al., 2008).

Through the drying kinetics it is possible to determine the behavior of the dry material, representing it by curves and drying rates (Menezes et al., 2013). The drying kinetics of several products can be described by semi-empirical or purely empirical mathematical models (Madamba, 2003). Therefore, the present work had as objective to determine the kinetics of drying of the chili pepper, to adjust different mathematical models to the experimental values as a function of the water content and to characterize the same in it's in natura form and after the drying in the temperatures of 60,70 and $80^{\circ} \mathrm{C}$.

\section{Method}

\subsection{Conduction of the Research}

The work was carried out in the Laboratory of Storage and Processing of Agricultural Products, Federal University of Campina Grande. The chili peppers used were acquired in the commerce of the city of Campina Grande, Paraiba, Brazil, then they were selected visually as for the elongated appearance of intense and bright green color for sampling uniformity (Figure 1A), cut into thin slices and the seeds were removed (Figure 1B).

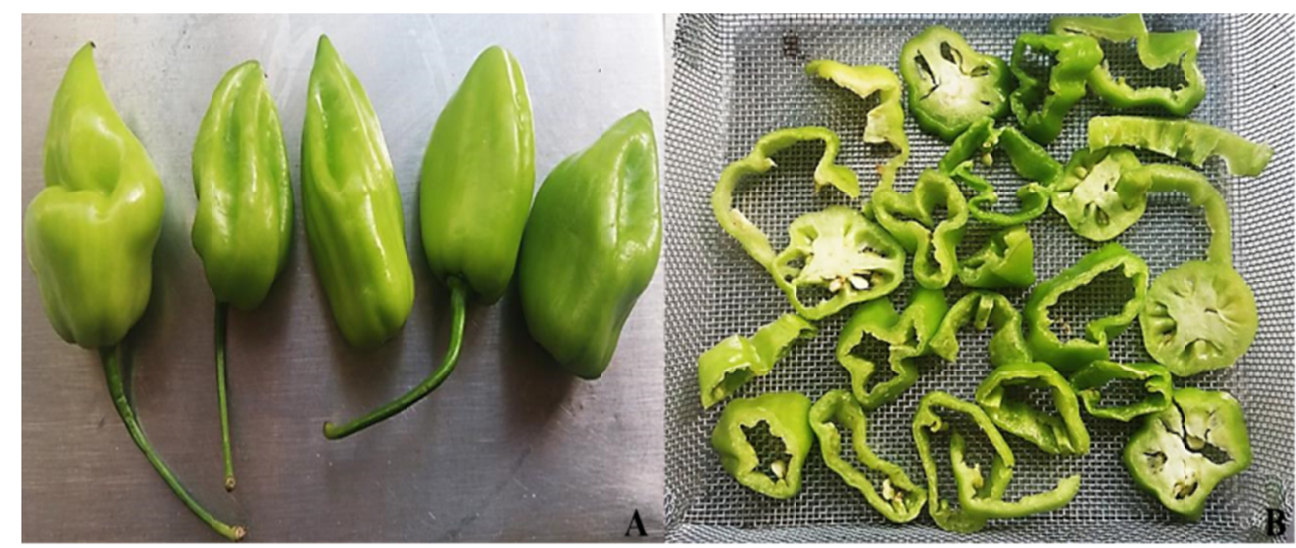

Figure 1. Whole and sliced chili pepper

\subsection{Drying Kinetics}

The drying was carried out with three replicates, using an oven with air velocity of $1 \mathrm{~m} / \mathrm{s}$, at the temperatures of 60,70 and $80{ }^{\circ} \mathrm{C}$, in which the samples were evenly distributed in steel screen trays, forming a double layer of approximately $0.5 \mathrm{~cm}$ thick.

For the drying process, the product was weighted at the beginning and thereafter at regular intervals until constant weight of the mass. From the experimental data the values of the moisture ratio were calculated according to Equation 1 (Chittennden \& Hustuld, 1966).

The initial and final water content of the pepper was determined according to Brasil (2008) in an oven at $105{ }^{\circ} \mathrm{C}$. From the data obtained during the drying graphics of the drying curve were designed (reduced mass as a function of time).

$$
\mathrm{MR}=\frac{\mathrm{X}-\mathrm{Xe}}{\mathrm{X} 0-\mathrm{Xe}}
$$

Where,

MR: moisture ratio, dimensionless; $\mathrm{X}$ : water content, dry basis (\%); $\mathrm{X}_{\mathrm{e}}$ : equilibrium water content, dry basis (\%); $\mathrm{X}_{\mathrm{o}}$ : initial water content, dry basis (\%). 
Five mathematical models were used to adjust the drying data, which are described in Table 1.

Table 1. Mathematical models used to adjust the drying data of the chili pepper at the temperatures of 60,70 and $80{ }^{\circ} \mathrm{C}$

\begin{tabular}{lll}
\hline Model designation & Equation & Reference \\
\hline Wang and Singh & $\mathrm{MR}=1+\mathrm{a} \cdot \mathrm{t}+\mathrm{b} \cdot \mathrm{t}^{2}$ & (Wang \& Singh, 1978) \\
Henderson and Pabis & $\mathrm{MR}=\mathrm{a} \cdot \exp (-\mathrm{k} \cdot \mathrm{t})$ & (Henderson \& Pabis, 1961) \\
Newton & $\mathrm{MR}=\exp (-\mathrm{k} \cdot \mathrm{t})$ & $\left(\mathrm{O}^{\prime}\right.$ Callaghan, et al., 1971) \\
Page & $\mathrm{MR}=-\mathrm{k} \cdot \mathrm{t}$ & (Page, 1949) \\
Thompson & $\mathrm{MR}=\exp \left[\frac{-\mathrm{a}-\left(\mathrm{a}^{2}+4 \cdot \mathrm{b} \cdot \mathrm{t}^{0,5}\right.}{2 \cdot \mathrm{b}}\right]$ & (Thompson et al., 1968)
\end{tabular}

Note. MR: moisture ratio of the product, dimensionless; t: drying time; k: drying coefficient; a, b: constants of the models.

For the application of the mathematical models of the experimental data, it was used the computer program Statistica 7.0 by means of non-linear regression analysis (Statsoft Co, 2007). The adjustment of each model was evaluated for the coefficient of determination $\left(\mathrm{R}^{2}\right)$ and Mean Square Deviation (MSD).

\subsection{Physicochemical Analysis}

The samples of chili pepper in natura were characterized physically and chemically and at the end of each drying as for the parameters: oven moisture at $105^{\circ} \mathrm{C}$; ashes by incineration in a muffle furnace; the total protein content was quantified by the Micro-Kjeldahl method, which consisted in the determination of the total nitrogen. To convert the result into protein, the factor 6.25 , recommended for vegetable proteins, was used according to the methodology described by Brasil (2008); $\mathrm{pH}$ with direct reading in digital $\mathrm{pH}$ meter, total acidity was obtained by titration and vitamin C, according to Brasil (2008) and lipids by the modified method of Bligh and Dyer (1959), $2.5 \mathrm{~g}$ of the sample was used which, after stirring for $30 \mathrm{~min}$ on magnetic stirrer, were added $20 \mathrm{~mL}$ of methyl alcohol, $20 \mathrm{ml}$ of chloroform, $10 \mathrm{ml}$ of sodium sulfate and $8 \mathrm{~mL}$ of distilled water. Subsequently, $5 \mathrm{~mL}$ of the sample was taken to the oven for $2 \mathrm{~h}$ at $80^{\circ} \mathrm{C}$ until the solvent evaporated. The samples were put to cool in desiccator and then weighed.

\subsubsection{Statistical Analysis}

The results of the drying were submitted to analysis of variance and the means were compared by the Tukey test at 5\% probability, using the statistical software Assistat 7.7 (Silva \& Azevedo, 2016).

\section{Results and Discussion}

The Figure 2 shows the drying kinetics of the thin layered chili pepper at different temperatures. It was noticed that the use higher temperatures reduce the drying time, in other words increased the rate of water loss. The drying time decreased from 310 to 160 min when the temperature increased from 60 to $70{ }^{\circ} \mathrm{C}$ and the drying time of 70 and $80^{\circ} \mathrm{C}$ were similar.

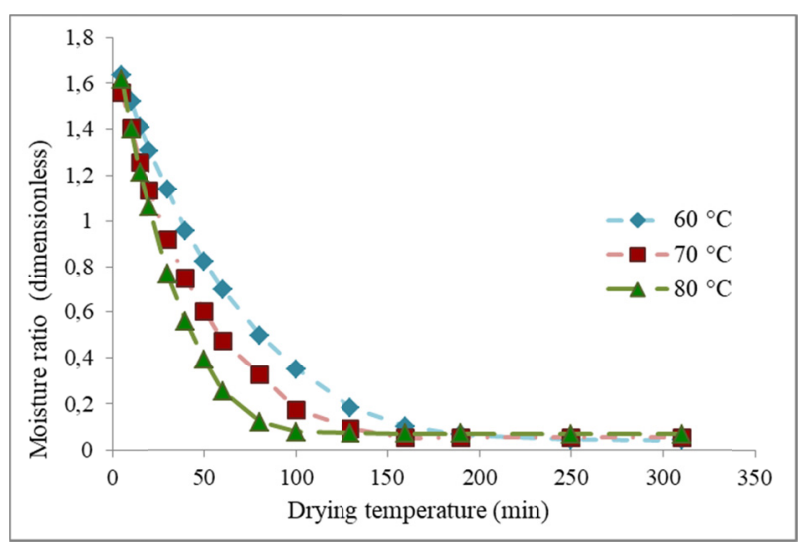

Figure 2. Drying kinetics of the chili pepper at different drying temperatures 
Melo et al. (2015) studying the drying of the chili pepper at the temperatures of 50,60 and $70{ }^{\circ} \mathrm{C}$, verified the drying times of 540, 490 and $400 \mathrm{~min}$, respectively, being the time lower with the increase in the temperature. Relating the studies, it was observed that the drying time in this work was inferior: $36.73 \%$ at $60{ }^{\circ} \mathrm{C}$ and $60 \%$ at $70^{\circ} \mathrm{C}$. This behavior is due to the fact that the higher rates of water removal of the product happen at the higher temperatures, which reduces the drying time.

In Table 2 are the values of the coefficients of determination $\left(\mathrm{R}^{2}\right)$ and the Mean Square Deviation (MSD) calculated to verify the adjustment of the mathematical models to the experimental data of the drying of the pepper at the temperatures of 60,70 and $80{ }^{\circ} \mathrm{C}$. It was observed that most of the models presented coefficients of determination $\left(\mathrm{R}^{2}\right)$ inferior to $90 \%$, this being considered an unsatisfactory adjustment, probably caused by variations of temperature detected in the equipment during the drying process.

Table 2. Parameters of adjustment of the drying kinetics of the chili pepper, coefficients of determination $\left(\mathrm{R}^{2}\right)$ and Mean Square Deviation (MSD) regarding the mathematical models at the temperatures of 60,70 and $80^{\circ} \mathrm{C}$

\begin{tabular}{|c|c|c|c|c|c|c|c|}
\hline \multirow{2}{*}{ Models } & \multirow{2}{*}{$\mathbf{T}\left({ }^{\circ} \mathbf{C}\right)$} & \multicolumn{4}{|c|}{ Parameters } & \multirow{2}{*}{$\mathbf{R}^{2}$} & \multirow{2}{*}{ MSD } \\
\hline & & $\mathbf{A}$ & $\mathbf{K}$ & B & $\mathbf{N}$ & & \\
\hline \multirow{3}{*}{ Wang and Singh } & 60 & -0.006 & - & 0.0001 & - & 72.466 & 0.245 \\
\hline & 70 & -0.008 & - & 0.00002 & - & 79.632 & 0.197 \\
\hline & 80 & -0.009 & - & 0.00002 & - & 75.401 & 0.219 \\
\hline & 60 & 1.542 & 0.012 & - & - & 91.778 & 0.134 \\
\hline \multirow[t]{2}{*}{ Henderson and Pabis } & 70 & 1.458 & 0.016 & - & - & 92.570 & 0.119 \\
\hline & 80 & 1.494 & 0.022 & - & - & 90.107 & 0.139 \\
\hline & 60 & - & 0.007 & - & - & 69.732 & 0.257 \\
\hline \multirow[t]{2}{*}{ Newton } & 70 & - & 0.010 & - & - & 77.459 & 0.207 \\
\hline & 80 & - & 0.013 & - & - & 75.636 & 0.218 \\
\hline \multirow{3}{*}{ Page } & 60 & - & 0.00014 & - & 1.896 & 79.541 & 0.211 \\
\hline & 70 & - & 0.00012 & - & 2.063 & 86.057 & 0.163 \\
\hline & 80 & - & 0.00018 & - & 2.137 & 84.948 & 0.171 \\
\hline \multirow{3}{*}{ Thompson } & 60 & -3248.27 & 4.882 & - & - & 69.732 & 0.257 \\
\hline & 70 & -2536.13 & 5.117 & - & - & 77.458 & 0.207 \\
\hline & 80 & -3059.01 & 6.514 & - & - & 75.636 & 0.218 \\
\hline
\end{tabular}

However, among the mathematical models analyzed, the model of Henderson and Pabis was the one that best fit the experimental data for presenting coefficient of determination with values higher than 90.00 and values of MSD lower than 0.139 for the studied temperatures (Figure 3).

Reis et al. (2015a) obtained behavior consistent with the coefficient $\mathrm{k}$ when determining and analyzing the drying kinetics of the bico pepper in different conditions of temperature.

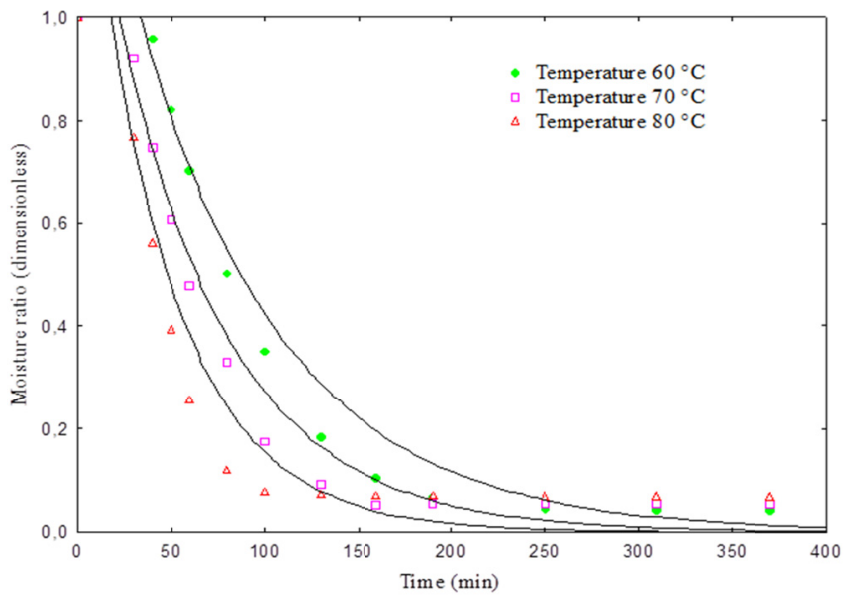

Figure 3. Drying curve of the chili pepper determined by the mathematical model of Henderson and Pabis at the drying temperatures of 60,70 and $80^{\circ} \mathrm{C}$ 
The results obtained for the physico-chemical evaluations of the in natura pepper were calculated, obtaining the means and the standard deviations (Table 3). The freshly squeezed pepper showed high moisture, which is related to its stability, quality, composition and can affect both its processing as well as its packaging and storage.

Table 3. Mean and standard deviation of the results obtained for the in natura sample

\begin{tabular}{ll}
\hline Parameters & Mean and standard deviation \\
\hline Moisture content (\%, w.b) ${ }^{1}$ & $92.43 \pm 0.07$ \\
pH & $6.94 \pm 0.02$ \\
Total acidity (\%) & $0.19 \pm 0.03$ \\
Lipids (\%) & $1.20 \pm 0.12$ \\
Ashes (\%) & $0.46 \pm 0.10$ \\
Proteins (\%) & $1.28 \pm 0.25$ \\
Vitamin C (mg of ascorbic acid/100g sample) & $43.65 \pm 0.49$ \\
\hline
\end{tabular}

Note. ${ }^{1}$ wet basis.

Lower values of $\mathrm{pH}(5.48)$ and acidity $(0.035 \%)$ were verified by Rebouças et al. (2013) when working with chili pepper in natura. In the in natura pepper, Dambros (2014) obtained values of ashes between 0.87 and 2.32 , superior to that verified in this research.

Pepper has great nutritional value, attributed to proteins, lipids and vitamins. Dantas et al. (2017) verified a total of $1.9 \%$ of proteins in samples of iniquitous black pepper, this was superior to that of this work. Studies performed by Valverde (2011) indicate values of $0.63 \%$ for lipids in chilli pepper in natura, a result that is lower than that verified in this research. Castro et al. (2008) verified $107.4 \mathrm{mg}$ of ascorbic acid/100 $\mathrm{g}$ of sample in chilli pepper, higher than that verified in this work for chilli pepper.

The results of the physicochemical analyzes at temperatures of 60,70 and $80{ }^{\circ} \mathrm{C}$ are described in Table 4 . There was a reduction in the moisture content, $\mathrm{pH}$, total acidity, lipids, ashes, proteins and vitamin $\mathrm{C}$ of the peppers submitted to drying.

Table 4. Mean values and standard deviation of the physical-chemical analyzes after drying at temperatures of 60 , 70 and $80^{\circ} \mathrm{C}$ of the chili pepper samples

\begin{tabular}{|c|c|c|c|}
\hline \multirow{2}{*}{ Parameters } & \multicolumn{3}{|c|}{ Drying temperatures } \\
\hline & $60^{\circ} \mathrm{C}$ & $70^{\circ} \mathrm{C}$ & $80^{\circ} \mathrm{C}$ \\
\hline Initial moisture content $(\%, \text { w.b })^{1}$ & $92.40 \mathrm{a}$ & $91.67 \mathrm{~b}$ & $91.23 \mathrm{~b}$ \\
\hline Final moisture content $(\%, \text { d.b })^{2}$ & $7.69 \mathrm{~b}$ & $9.41 \mathrm{a}$ & $7.15 \mathrm{~b}$ \\
\hline $\mathrm{pH}$ & $4.59 \mathrm{a}$ & $4.57 \mathrm{ab}$ & $4.39 \mathrm{~b}$ \\
\hline Total acidity $(\%)$ & $2.20 \mathrm{a}$ & $2.19 \mathrm{a}$ & $2.19 \mathrm{a}$ \\
\hline Lipids (\%) & $5.39 \mathrm{a}$ & $5.38 \mathrm{a}$ & $5.23 \mathrm{~b}$ \\
\hline Ashes $(\%)$ & $14.95 \mathrm{a}$ & $7.33 \mathrm{~b}$ & $6.29 \mathrm{c}$ \\
\hline Proteins $(\%)$ & $2.46 \mathrm{a}$ & $2.36 \mathrm{~b}$ & $2.37 \mathrm{~b}$ \\
\hline Vitamin C (mg of ascorbic acid/100g sample) & $18.58 \mathrm{a}$ & $16.64 \mathrm{~b}$ & $15.29 \mathrm{c}$ \\
\hline
\end{tabular}

Note. Means followed by the same letter do not differ statistically from each other by the Tukey test at the level of $5 \%$ of probability. ${ }^{1}$ wet basis; ${ }^{2}$ dry base.

During the drying process changes in the quality parameters occurred. The drying with hot air leads to a decrease in nutritional values, besides altering texture, color and causing a slow or incomplete rehydration of the material (Braga, 2007). By evaluating the influence of drying, it was observed that the exposure to heat caused a reduction in the parameters of moisture, $\mathrm{pH}$ and vitamin $\mathrm{C}$ when compared to the dry and in natura pepper. Regarding ash and vitamin $\mathrm{C}$ values, it can be observed that the gradual increase of the treatment temperature caused significant losses among the dry samples. 
The mean value of the $\mathrm{pH}$ found in the chili pepper sample was higher than that verified by Braga et al. (2013), in which $\mathrm{pH}$ values varying from 5.13 to 5.57 were found in fruits of five progenies of chili pepper. More acidic fruits are naturally more stable to deterioration than foods that have $\mathrm{pH}$ close to neutrality. According to Braga et al. (2012) the $\mathrm{pH}$ measurement is an important parameter for the determination of a possible and quick deterioration of the product due to the presence and growth of microorganisms harmful to health.

It was verified a reduction in the $\mathrm{pH}$ of the samples after the drying process. Braga et al. (2013), found values of 5.13 to 5.57 in fruits of five progenies of chilli pepper cultivated in the county of Sobral-CE. Quintero-Ramos et al. (1998), in a study evaluating peppers, observed a decrease in the $\mathrm{pH}$ value with the increase of the drying temperature. In this case, the authors attributed this drop to the presence of free carboxylic groups, generated from the demethoxylation of the pectin from the pectin methylesterase action present in the cell wall of the plants. More acidic fruits are, naturally, more stable to deterioration than foods that have $\mathrm{pH}$ close to neutrality.

For the acidity value, Borges et al. (2015) verified a value of $0.156 \%$ for the Capsicum spp., which is lower than the results verified in this research. According to Reis et al. (2015b), the lower the content of titratable acidity in the fruit, the better is its conservation status, which directly reflects in the quality of a final product for consumption.

Regarding the lipids, Reis et al. (2015b) obtained value (0.20\%) for the pepper of the bico variety, which is lower than that verified in this study. As for the ashes result, Farias (2013) that worked with the yield of the peppers of the genus Capsicum obtained $1.09 \%$, being, therefore, lower than that verified in this work for dry pepper. Lower values of proteins were verified by Rinaldi et al. (2008) when studying the varieties of pepper Paloma Hidropônico, Paloma Campo, Impacto Hidropônico and Magali Campo, in which values ranging from 0.09 to $0.12 \%$ were found.

Valverde (2011) performed chemical determinations on fresh and processed chilli pepper and observed that there were no differences between protein and lipid contents. There was a reduction in vitamin $\mathrm{C}$ content due to exposure to heat, both temperatures presented significant statistical difference. According to Gabas et al. (2003), the loss of ascorbic acid is affected mainly by the application of high temperatures. Valverde (2011) verified for the ascorbic acid content the loss of $88.06 \%$ of the pepper in natura compared to the processed one. Passos et al. (2012) also observed reduction of ascorbic acid from 20.46 to $17.30 \%$ in the Moringa oleifera leaves during the convective drying process. The vitamins are very sensitive compounds and can be degraded by several factors, such as temperature, oxygen presence, light, moisture, $\mathrm{pH}$, duration of treatment to which the food was subjected, among others (Rebouças et al., 2013).

\section{Conclusions}

The model of Henderson and Pabis was the one that best fit to the experimental data. The increase of the drying temperature promoted a reduction in the time required for the peppers to reach the moisture of the hygroscopic balance. The drying constant $(\mathrm{k})$ increased with the raise of temperature, indicating that the drying rate increased with the raise of this variable in the process. The parameters of acidity, lipids and proteins remained close at the different drying temperatures used, however higher when compared to the samples in natura. It can be noticed that ashes and vitamin $\mathrm{C}$ have suffered considerable decrease as the temperature increased, as a result of the chemical transformations that occurred in the peppers due to heat exposure and loss of moisture.

\section{References}

Araújo, E. I. M., Freire, L. C. C., Alves, L. A., \& Bertini, L. M. (2013). Caracterização fitoquímica e atividade antioxidante dos extratos em etanol de Capsicum chinense (Pimenta de Cheiro) (pp. 597-603). Congresso de iniciação científica do IFRN, 9.

Bligh, E. G., \& Dyer, W. J. (1959). A rapid method of total lipid extraction and purification. Canadian Journal Biochemistry Physiology, 37, 911-917. https://doi.org/10.1139/y59-099

Borges, K. M., Vilarinho, L. B. O., Melo Filho, A. A., Morais, B. S., \& Rodrigues, R. N. S. (2015). Caracterização morfoagronômica e físico-química de pimentas em Roraima. Revista Agro@mbiente On-line, 9, 292-299. https://doi.org/ 10.18227/1982-8470ragro.v9i3.2766

Braga, A. M. P. (2007). Estudo da retenção de constituintes voláteis na secagem de abacaxi sob atmosfera modificada (Dissertação de Mestrado, Universidade Estadual de Campinas, Campinas, Brazil).

Braga, T. R., Pereira, R. C. A., Silva, L. R., Crisostomo, J. R., Silveira, M. R. S., Bezerra, F. C., \& Oliveira, M. M. T. (2012). Caracterização físico-química de progênies de pimentas cultivadas em Sobral-CE. Horticultura Brasileira, 30, 6068-6074. 
Braga, T. R., Pereira, R. C. A., Silveira, M. R. S., Silva, L. R., Silva, A. R., \& Oliveira, M. M. T. (2013). Caracterização físico-química de progênies de pimentas (Capsicum frutescens L.). Revista de la Facultad de Agronomía, 112, 6-10.

Brasil, Instituto Adolfo Lutz. (2008). Métodos fisico-químicos para análise de alimentos (4th ed., Volume 1, p. 1020). São Paulo: Instituto Adolfo Lutz.

Castro, S. M., Saraiva J. A, Lopes, S. J. A., Delgadillo, I., Loey, A. V., Smout, C., \& Hendrickx, M. E. (2008). Effect of thermal blanching and of high pressure treatments on sweet green and red bell pepper fruits (Capsicum annuum L.). Food Chemistry, 107, 1436-1449. https://doi.org/10.1016/j.foodchem.2007.09.074

Cerqueira, P. A. (2012). Conservação pós-colheita de pimentas de cheiro (Capsicun chinense) armazenadas sob atmosfera modificada e refrigeração (Dissertação de Mestrado, Universidade de Tocantins, Gurupi, Brazil).

Chittenden, D. H., \& Hustrulid, A. (1966). Determining drying constant for shelled corn. Transactions of American Society of Agricultural Engineers, 9, 52-55. https://doi.org/ 10.13031/2013.39872

Dambros, J. I. (2014). Estabilidade de compostos potencialmente bioativos e alterações de qualidade em frutos e produtos de pimenta (Capsicum spp.) (Dissertação de Mestrado, Universidade Federal de Pelotas, Pelotas, Brazil).

Dantas, E. R., Araújo, A. dos S., Silva, E. V. da., Paiva, Y. F., Calado, J. A., \& Lima, R. R. de. (2017). Extrato da Pimenta 'Biquinho' como revestimento comestível na conservação de goiabas. Revista Verde de Agroecologia e Desenvolvimento Sustentável, 12, 695-700. https://doi.org/10.18378/rvads.v12i4.4931

Faria, R. Q., Teixeira, I. R., Devilla, I. A., Ascheri, D. P. R., \& Resende, O. (2012). Cinética de secagem de sementes de crambe. Revista Brasileira de Engenharia Agrícola e Ambiental, 16, 573-583. https://doi.org/ $10.1590 /$ S1415-43662012000500014

Farias, V. L. (2013). Aumento do rendimento do extrato de pimenta (Capsicum frutescens L.): Utilização de preparações enzimáticas comerciais (Tese de Doutorado, Universidade Federal do Ceará, Fortaleza, Brazil).

Gabas, A. L., Telis-Romero, J., \& Menegalli, F. C. (2003). Cinética de degradação do ácido ascórbico em ameixas liofilizadas. Ciência e Tecnologia de Alimentos, 23, 66-70. https://doi.org/10.1590/S0101-20612 003000400013

Henderson, S. M., \& Pabis, S. (1961). Grain drying theory I: Temperature effect on drying coefficient. Journal of Agricultural Engineering Research, 6, 169-174.

Madamba, P. S. (2003). Thin layer drying models for osmotically pré-dried young coconut. Drying Technology, 21, 1759-1780. https://doi.org/10.1081/DRT-120025507

Melo, J. C. S., E. D., Pereira, K. P., Oliveira, Costa, C. H. C., \& Feitosa, R. M. (2015). Estudo da cinética de secagem da pimenta de cheiro em diferentes temperaturas. Revista Verde de Agroecologia e Desenvolvimento Sustentável, 10, 09-14. https://doi.org/10.18378/rvads.v10i2.3165

Menezes, M. L., A. P., Ströher, N. C. Pereira., \& Barros, S. T. D. (2013). Análise da cinética e ajustes de modelos matemáticos aos dados de secagem do bagaço do maracujá-amarelo. Revista Engevista, 15, 176-186. https://doi.org/10.22409/engevista.v15i2.443

O’Callaghan, J. R., Menzies, D. J., \& Bailey, P. H. (1971). Digital simulation of agricultural dryer performance. Journal of Agricultural Engineering Research, 16, 223-244. https://doi.org/10.1016/S0021-8634(71) 80016-1

Oliveira, J. R. de., Gomes R. L. F., Araújo, A. S. F., Marini, F. S., Lopes, J. B., \& Araújo, R. M. (2014). Estado nutricional e produção da pimenteira com uso de biofertilizantes líquidos. Revista Brasileira de Engenharia Agricola e Ambiental, 18, 1241-1246. https://doi.org/10.1590/1807-1929/agriambi.v18n12p1241-1246

Page, G. E. (1949). Factors influencing the maximum rate of air drying shelled corn in thinlayers (M.S. Thesis, Purdue University, West Lafayette, Indiana).

Passos, R. M., Santos, D. M. C., Silva, B. S., Bery, C. C. S., Santos, J. A. B., \& Silva, G. F. (2012). Influência da secagem solar na composição físico-química da folha e vagem da Moringa oleífera Lam. Encontro Nacional da Moringa, Campina Grande.

Quintero-Ramos, A., Bourne, M. C., Barnard, J., \& Anzaldúa-Morales, A. (1998). Optimization of low temperature blanching of frozen jalapeño pepper (Capsicum annuum) using response surface methodology. Journal of Food Science, 63, 519-522. https://doi.org/10.1111/j.1365-2621.1998.tb15777.x 
Radunz, L. L., Amaral, A. S., Mossi, S. J., Melo, E. C., \& Rocha, R. P. C. (2011). Avaliação da cinética de secagem da carqueja. Revista Engenharia na Agricultura, 19, 19-27. https://doi.org/10.13083/reveng. v19i1.147

Rebouças, T. N. H., Valverde, R. M. V., \& Teixeira, H. L. (2013). Bromatologia da pimenta malagueta in natura e processada em conserva. Horticultura Brasileira, 31, 163-165. https://doi.org/10.1590/S0102-05362013 000100026

Rêgo, E. R., Rêgo, M. M., Matos, I. W. F., \& Barbosa, L. A. (2011). Morphological and chemical characterization of fruits of Capsicum spp. accessions. Horticultura Brasileira, 29, 364-371. https://doi.org/ $10.1590 / \mathrm{S} 0102-05362011000300018$

Reis, D. R. D., Dantas, C. M. B., Silva, F. S., Porto, A. G., \& Soares, E. J. O. (2015a). Caracterização biométrica e físico-química de pimenta variedade biquinho. Enciclopédia Biosfera, 11, 454.

Reis, D. R., Santos, P., Silva, F. S., \& Porto, A. G. (2015b). Influência das características do ar na cinética de secagem de pimenta variedade bico. Brazilian Journal Food Technology, 18, 146-154. https://doi.org/ $10.1590 / 1981-6723.6214$

Reis, R. C., Barbosa, L. S., Lima, M. L., Reis, J. S., Devilla, I. A., \& Ascheri, D. P. R. (2011). Mathematical modeling of drying kinetics of pepper Cumari do Para. Revista Brasileira de Engenharia Agrícola e Ambiental, 15, 347-353. https://doi.org/10.1590/S1415-43662011000400003

Resende, O., Corrêa, P. C., Goneli, A. L. D., Botelho, F. M., \& Rodrigues, S. (2008). Modelagem matemática do processo de secagem de duas variedades de feijão (Phaseolus vulgaris L.). Revista Brasileira de Produtos Agroindustriais, 10, 17-26. https: //doi.org/10.15871/1517-8595/rbpa.v10n1p17-26

Resende, O., Ferreira, L. U., \& Almeida, D. P. (2010). Modelagem matemática para descrição da cinética de secagem do feijão adzuki (Vigna angularis). Revista Brasileira de Produtos Agroindustriais, 12, 171-178. https://doi.org/10.15871/1517-8595/rbpa.v12n2p171-178

Rinaldi, M. M., Sandri, D., Ribeiro, M. O., \& Amaral, A. G. (2008). Características físico-químicas e nutricionais de pimentão produzido em campo e hidroponia. Ciência e Tecnologia de Alimentos, 28, 558-563. https://doi.org/10.1590/S0101-20612008000300009

Rufino, J. L. S., \& Penteado, D. C. S. (2006). Importância econômica, perspectivas e potencialidades do mercado para pimenta. Informe Agropecuário, 27, 7-15.

Santos, B. A. J., Silva, F. G., \& Pagani, C. A. A. (2012). Estudo Cinético de secagem da pimenta malagueta (Capsicun spp) cultivado no estado de Sergipe. Revista Geintec, 2, 465-471. https://doi.org/10.7198/S2237 $-0722201200050004$

Sediyama, M. A. N., Santos, M. R. dos., Vidigal, S. M., Pinto, C. L. de O., \& Jacob, L. L. (2014). Nutrição e produtividade de plantas de pimentão colorido, adubadas com biofertilizante de suíno. Revista Brasileira de Engenharia Agrícola e Ambiental, 18, 588-594. https://doi.org/10.1590/S1415-43662014000600004

Silva, F. A. S., \& Azevedo, C. A. V. (2016). The Assistat Software Version 7.7 and its use in the analysis of experimental data. African Journal Agricultural Research, 11, 3733-3740. https://doi.org/10.5897/AJAR 2016.11522

Statsoft. (2007). Statistica for Window—Computer programa manual (Versão 7.0). Tulsa: Statsoft Inc.

Thompson, T. L., Peart, R. M., \& Foster, G. H. (1968). Mathematical simulation of corn drying: A new model. Transactions of American Society of Agricultural Engineers, 11, 582-586. https://doi.org/10.13031/2013. 39473

Valverde, R. M. V. (2011). Composição bromatológica da pimenta malagueta in natura e processada em conserva (Dissertação de Mestrado, Universidade Estadual do Sudoeste da Bahia, Itapetinga, Brazil).

Wang, C. Y., \& Singh, R. P. (1978). Use of variable equilibrium moisture content in modeling rice drying. Transactions of American Society of Agricultural Engineers, 11, 668-672.

\section{Copyrights}

Copyright for this article is retained by the author(s), with first publication rights granted to the journal.

This is an open-access article distributed under the terms and conditions of the Creative Commons Attribution license (http://creativecommons.org/licenses/by/4.0/). 